\title{
Implementation of the online learning during Covid-19: Between obligations and barriers
}

\section{Ummi Mukarromah *, Wiwik Wijayanti}

Graduate School, Universitas Negeri Yogyakarta.

Jl. Colombo No.1, Karang Malang, Depok, Sleman, Daerah Istimewa Yogyakarta 55281, Indonesia.

* Corresponding Author. Email: ummimukarromah.2019@student.uny.ac.id

\section{ARTICLE INFO}

\section{Article History}

Received:

31 December 2021;

Revised:

28 February 2021;

Accepted:

12 March 2021;

Available online:

20 August 2021

\section{Keywords}

Covid-19;

Digital competence;

Hard skills;

Hotel accommodation;

Soft skills

\begin{abstract}
Vocational schools are no exception to implementing the online learning policy during the covid-19 pandemic, including students majoring in hotel accommodation. This study describes how the school develops its readiness to implement the policy, particularly its challenges. This study also aims to determine the constraints and impacts of implementing the policy. Using a qualitative method, this study involved two vocational schools in Yogyakarta that have a hotel accommodation field. The head of the departments, the productive teachers, and some students was invited to several interviews. Documentation was also used to obtain detailed information. The results were categorized into two aspects: hard skills and soft skills. From the first aspect, challenges faced as the policy's impact are: 1.) Online learning at vocational schools majoring in hotel accommodation requires facilities and infrastructure that do not include internet quota; 2.) Teacher digital competence and teacher creativity in carrying out learning needs to be improved; 3.) Students feel bored with online learning, so motivation needs to be grown; and 4.) Skills/ practice-based learning implemented in school alternately with a limited number of students. The second aspect indicated that the policy makes it difficult to develop students' soft skills that are also measured as the learning objective. These constraints are important to note for the implementation of the online learning policy to be successful.
\end{abstract}

This is an open access article under the CC-BY-SA license.

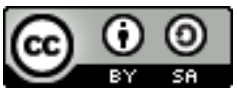

\section{How to cite:}

Mukarromah, U., \& Wijayanti, W. (2021). Implementation of the online learning during Covid-19:

Between obligations and barriers. Jurnal Pendidikan Vokasi, 11(1), 92-101.

https://doi.org/10.21831/jpv.v11i1.37110

\section{INTRODUCTION}

Since the beginning of 2020, all countries in the world have been in the period of the Covid19 Pandemic, which resulted in drastic changes in education. The Indonesian Minister of Education swiftly responded to the situation by issuing a policy and following up on the implementation of education during the pandemic, namely issuing circular letter No. 4 of 2020 concerning the implementation of education policies in the emergency of the spread of Covid-19. In this policy, it is stated that the teaching and learning process is carried out from home over a distance and is carried out to provide a meaningful learning experience for students without being burdened with demands to complete all curriculum achievements for class promotion and graduation. Distance learning policy, or what is commonly called online learning, is learning that is carried out by electronic means, usually with an internet network, and can also be done by video conferencing via satellite networks (Triyono \& Utami, 2017). 
The same thing was done in other countries such as China and Turkey. The Chinese government launched a policy to continue teaching and learning activities because schools were closed, suspending classes without stopping learning (Zhang et al., 2020). Likewise, the Turkish Ministry of National Education issued a similar policy of closing schools and replacing them with online learning (Özer, 2020). The two countries' policies show that it was not only the Indonesian government that launched a new education policy in an emergency period of the spread of Covid-19. This policy does require a quick response so that learning at school continues, even though the school is closed. A book entitled "E-learning a guidebook of principles, procedure, and practice" explains that online learning is commonly referred to as the intentional use of networked information and communications technology in teaching and learning. Several other terms are also used to describe this mode of teaching and learning. They include online learning, virtual learning, network, and webbased learning (Naidu, 2006). The term e-learning or electronic learning is often referred to as distance learning, an education system whose implementation separates educators from students, who are separated due to distance and time factors (Triyono \& Utami, 2017). From the above definition, it can be concluded that distance learning is an educational system or concept that utilizes information technology in the learning process carried out without having to face to face directly between educators and students. The policy issued by the Minister of Education of the Republic of Indonesia was the right decision to prevent the spread of Covid-19 in the school environment and to keep education going even though it was a distance.

This policy's realization needs to be studied and considered at every formal education level, including a vocational school. Vocational School is a school that prioritizes and focuses on the skills of students who are prepared to enter the world of work. Regarding the Covid-19 pandemic, learning at vocational schools in all majors has also been affected. Learning at vocational school requires essential skills taught through basic practices following vocational to productive subjects, a vocational school in hotel accommodation expertise. They cannot do practical learning at school to enter the industrial world, such as carrying out learning related to the hospitality sector, namely housekeeping, front office, food \& beverage, and laundry.

Implementing educational policies in hospitality accommodation Vocational High Schools has challenges on hard skills and soft skills from both educators or students. Hard skills are a science, and each student's ability is following their respective fields. In contrast, soft skills are student skills during practice in the field, extracurricular activities, and character training. Soft skills are special abilities that can improve a person's job performance and career prospects (Abdullah-Al-Mamun, 2012). As we know, vocational school is one of the school levels that focuses on student competency skills to provide a hands-on practical learning experience as capital to enter the world of work. Therefore, learning at a vocational school not only on students' hard skills but also on students' soft skills because soft skills have a strategic role in determining someone's success in their work (Wagiran, 2008).

The implementation of policies in schools requires schools to continue to implement learning even though schools are closed. In a pandemic like today, all activities require digitization, including learning. Teacher competence in providing online lessons to students needs to be considered to foster students' hard skills and soft skills. Teaching in vocational school requires certain strategies, especially teaching strategies related to computers. It takes the skills of a teacher to operate an e-learning plan as a learning medium. Teachers must know the appropriate learning design for vocational school and what is needed in implementing e-learning based learning (Triyono, 2015). A study from Lucas et al. (2021) reveals that teachers' proficiency in digital competencies is still low and needs improvement. Teacher skills in implementing digital learning determine the meaning of online learning for students, while currently, students feel a lack of conversation between students and teachers in online learning (Aydin et al., 2015). Therefore, teachers' digital competence is the main factor in determining online vocational school learning success.

Another factor that can support implementation is student motivation. Student learning motivation in participating in distance learning is the focus of teacher attention. Learning through elearning, student interest, and motivation need to grow to not get bored following the learning process. The Covid-19 pandemic impacts student learning because many of them are not used to doing distance learning. A study stated that online learning had been carried out in many public and 
private vocational schools, the availability of facilities and their use supports the online learning process. However, students generally stated that online learning was no more interesting than ordinary learning, even though most of them understood the lessons taught and were allowed by the teacher to actively participate during the learning process (Mulyanti et al., 2020). This condition illustrates that student learning motivation during pandemics has decreased. Therefore, the teacher needs to consider student learning motivation to avoid getting bored in online learning.

At this time, facilities and infrastructure play an essential role in realizing the success of online learning. In the study (Mulyanti et al., 2020), it was also stated that the online learning facilities at public vocational schools West Java were at 35.3\% (not good) and $17.32 \%$ (bad). This reflects that the facilities at vocational schools in implementing online learning need to be improved even though most of them are in good condition and available. A big challenge for an institution is to meet the facilities for teachers and students in online learning. Students with incomplete/outdated facilities will find it difficult to follow the teacher's online learning techniques (Adedoyin \& Soykan, 2020). Based on some of the problems above, the researcher is interested in conducting a study showing how schools, especially the vocational school level, especially the vocational school in hotel accommodation, implement the government's policies. Researchers want to explore how practical learning is applied in online learning at vocational schools and know the constraints and impacts of implementing the policy. For this reason, researchers conduct policy analysis research that focuses on its implementation to obtain a comprehensive overview and information on applied policies.

\section{RESEARCH METHOD}

Qualitative research is chosen to enable the researchers to gain insight into certain social phenomena' meaning and specific behavior (Palmer \& Bolderston, 2006). With qualitative research, researchers can find an in-depth, comprehensive picture of certain phenomena and make interpretations of what they see, hear, and understand (Creswell, 2013). This research lasted for one month, from 15 October to 15 November 2020. The research subjects were invited from two vocational schools in Yogyakarta, which already have a hotel management practice laboratory or what is commonly called an edotel (educational hotel) independently and is leased to the public. These schools are public or owned by the Government, which means implementing the same school managerial system. Yogyakarta is located in the middle of Java island and is named a tourism province since there are almost heritage sites in every district. Besides Yogyakarta, are cultural city and tourist city, it is also known as a student city. Therefore, many hotel sectors have developed in Yogyakarta, so that the hospitality accommodation department is one of the areas of interest to study in vocational schools.

Data was gathered through interviews and documentation. The researchers interviewed two heads of the hotel accommodation department, two teachers of productive subjects, and four students. Interviews with teachers of productive subjects based on recommendations from the head of the department are teachers who have good competence in online learning and master various learning platforms. 2 teachers were selected, namely the front office and laundry subject teachers. Students selected as respondents are students who actively participate in online learning based on the teacher's observations of the hotel accommodation major. Interview data are supported by documents in the form of syllabus and lesson plans for productive subjects, namely front office, housekeeping, food $\&$ beverage, and laundry. The researcher collected data in depth by collecting narrative material using a flexible research design (Moser \& Korstjens, 2017).

The data that has been collected is analyzed using descriptive analysis, which describes the problem of the object that has been collected, and then conclusions are drawn (Moser \& Korstjens, 2018). The analysis begins by describing and interpreting the information related to the challenges and impacts of implementing online learning policies at the vocational school in the hotel accommodation department. Researchers describe the interviews' results and identify challenges and their impact from the interview transcripts' results. The validity of the data in this study used persistence and triangulation of research subjects. Triangulation is done triangulation of sources and research techniques. For example, researchers get information during interviews with the head of the study program, and this information is also confirmed to teachers of productive subjects and students. 
To support the interview results, the researcher asked for documents from what was conveyed during the interview.

\section{RESULT AND DISCUSSION}

The condition of the world of education since the beginning of 2020 is being shaken with the emergence of Covid-19, which results in learning that must take advantage of information technology and be carried out remotely (Viner et al., 2020). The online learning process involves information technology to transfer knowledge remotely using various internet platforms. To find out about the implementation of online learning policies at State Vocational High Schools in hotel accommodation, a field study was carried out with interviews and documentation at 2 Vocational Schools with the hotel accommodation department. Based on interviews and documentation results, school readiness to implement online learning policies is categorized into two aspects: hard and soft skills in hospitality accommodation.

\section{Hard Skill Aspect \\ Facilities and Infrastructure}

Based on researchers' data, the challenge of implementing online learning that impacts hard skills is the availability and readiness of facilities. Several obstacles were found in implementing policies that have been formulated to improve and maintain the quality of learning. Constraints experienced by schools in providing online learning facilities can be seen in Table 1.

Table 1. Obstacles in Infrastructures

\begin{tabular}{lll}
\hline No. & \multicolumn{1}{c}{ Obstacles } & \multicolumn{1}{c}{ Impact } \\
\hline $\begin{array}{l}\text { Availability of student phones/ PC/ Laptop } \\
\text { at home }\end{array}$ & $\begin{array}{l}\text { Inhibiting some students when going to take lessons } \\
\text { online, students in low family economic conditions } \\
\text { some do not have facilities, and some use one facility } \\
\text { for shared needs with their families }\end{array}$ \\
$2 \quad \begin{array}{l}\text { Internet quota from the government is not } \\
\text { comprehensive for all providers, and the } \\
\text { number of packages given is limited }\end{array}$ & $\begin{array}{l}\text { Limiting students to take online learning, students } \\
\text { having difficulty taking lessons with video conference } \\
\text { platforms, or learning consumes many quotas. } \\
\text { Certain locations are constrained in signal strength, so } \\
\text { that some students have difficulty following online } \\
\text { learning. }\end{array}$ \\
\hline
\end{tabular}

Learning that is carried out in all schools, including in vocational schools majoring in hospitality accommodation online, is carried out remotely requires adequate facilities. Academic resources' readiness to carry out online learning in certain areas of expertise impacts learning success and student learning fulfillment. The implementation of online learning is quite surprising for some people because they have to prepare facilities that can be used to learn from home. The main obstacle to this implementation is the low family economy, making it difficult to provide infrastructure or online learning facilities (Atsumbe et al., 2012). Based on identifying barriers to facilities' availability, we can see that facilities for online learning are essential. Because without these facilities, students cannot participate in learning. Vocational education online learning, especially in hotel accommodation, has unique characteristics that emphasize practical skills (Triyono \& Utami, 2017).

This online learning is not enough to have a cellphone/laptop that can be used for learning, but an internet connection also needs to be considered. The internet quota needed by students at home must also be fulfilled so that distance learning can run smoothly. Many students complain about this online learning because it consumes many quotas. The majority of students support the initiative to implement online learning programs. However, on the other hand, during Covid-19, students spent much money buying internet data for online learning (Demuyakor, 2020). Student complaints about 
online learning arise when there are many assignments from teachers like have to watch or download learning videos, which will drain a lot of internet quota.

Internet quotas are the primary means for teachers and students to carry out online learning. Responding to teachers' and students' complaints, the Ministry of Education and Culture inaugurated the 2020 internet quota assistance policy to help teachers, students, students, and lecturers while carrying out distance learning. Quoted from the kemendikbud.go.id page, the Indonesian Minister of Education provided internet quota assistance of $20 \mathrm{~GB}$ for early childhood education, $35 \mathrm{~GB}$ for primary and secondary education, $50 \mathrm{~GB}$ for higher education (Ministry of Education and Culture of the Republic of Indonesia, 2020). The quota of assistance can be used to access the learning website, and $5 \mathrm{~GB}$ is used for the general quota. In addition to complaints about the quantity of internet quota, some students also complained about difficult geographic conditions to get a signal, which hindered the learning process. Some students in these 2 Vocational High Schools feel constraints on geographical conditions because the school's location is near hills, not the majority, and those who experience it.

Weak signals in remote areas and the cost of data quotas pose challenges in online learning (Sadikin et al., 2020). The cost of quotas hinders the use of online learning facilities (Atsumbe et al., 2012). Students must study with a stable internet connection, which is difficult for those who live in areas that do not have good internet access (Putra et al., 2020). Online learning at vocational schools in the hotel accommodation department requires adequate facilities ranging from cellphones, internet quotas and is supported by a strong signal. The productive subjects like the front office, housekeeping, and laundry require special skills that students must master. Therefore, with good facilities, online learning at vocational schools, majoring in Hotel accommodation will also be of quality because the facilities and infrastructure are the primary and first things that must be fulfilled to carry out online learning during a pandemic.

\section{Digital Teacher Competence}

Good digital teacher competencies support students' hard skills in online learning. Teachers who master digital and can make good use of their competencies will also present good material for their students, especially when learning online. The researcher obtained information that there were several obstacles related to teachers' digital competence based on the interview results. The obstacles faced by schools can be seen in Table 2 .

Table 2. Obstacles and Impacts of Teacher's Digital Competence

\begin{tabular}{lll}
\hline No. & \multicolumn{1}{c}{ Obstacles } & \multicolumn{1}{c}{ Impact } \\
\hline 1 & $\begin{array}{l}50 \% \text { of teachers cannot use the learning } \\
\text { platform yet. Some monotonous teachers } \\
\text { use 1 platform that is used to convey } \\
\text { assignments / provide material to } \\
\text { students }\end{array}$ & $\begin{array}{l}\text { Online learning uses platforms that are familiar and } \\
\text { mastered by teachers, such as Google Classroom and }\end{array}$ \\
WhatsApp & $\begin{array}{l}\text { The teacher makes new administrative documents, } \\
\text { namely the RPP, which is shortened and refers to the } \\
\text { plans during a pandemic increases the } \\
\text { workload of teachers }\end{array}$ & $\begin{array}{l}\text { previous RPP. In addition to making new lesson plans, } \\
\text { teachers must learn the right platform in planning } \\
\text { lessons. }\end{array}$ \\
\hline
\end{tabular}

Information and communication technology (ICT), particularly teacher digital competence, plays an important role in online teaching during school closures due to the Covid-19 pandemic and is a challenge for teachers to learn and deepen digital competence (König et al., 2020). In the digital era, especially in the Industrial Revolution 4.0, teachers must be digitally literate to use technology to deliver and support education (Ally, 2019). The implementation of online learning needs to be supported by educators' ability to use online learning communication tools or tools such as email, web, blogs, google classroom, google meet, and others. Based on interviews with productive vocational subject teachers in hotel accommodation, teachers' digital competence needs to be continuously improved in implementing policies. 
This is in line with research conducted by Lucas et al. (2021), which states that teachers' digital competence is still low and needs to be improved. In addition to facilities and infrastructure, teacher competence is the main requirement for facilitating online learning, especially for SMKs that prioritize practice rather than theory. Teachers' demands in online learning are increasing competence in digital mastery, but creativity in providing and presenting material for online learning must also be improved.

Lesson planning is also a fundamental role for successful online learning (Aydin et al., 2015). The learning plan at vocational school is outlined in a lesson plan prepared by the teacher, specifically for online learning. This was obtained from the documentation results in two schools where the study was conducted, wherein in normal conditions, the teacher had originally prepared the lesson plans. Still, during the pandemic, the teachers were asked to make special lesson plans for emergency conditions that adopted the previous lesson plans. This online learning adds to the workload of teachers for learning preparation that will be provided to students. Preparations that must be done include preparing online teaching materials using attractive media, creating and determining learning portals, preparing a container in the portal so that learning activities can run. MattersIncreasing and changing workloads for teachers with online education can support many students but need to be carefully designed and prepared carefully (Kaden, 2020). The demand to prepare online learning makes teachers feel the workload increases.

Based on this information, teachers need to improve their abilities in digital learning. In addition to using various learning platforms, they also need to present material to students attractively. Presenting interesting content can increase the ease and comfort of learning so that learning is more quality (Wahyuningsih \& Makmur, 2017). The ability to use technology and access information technically must be mastered by educators in implementing online learning. Educators who are familiar with and adaptable to online technology will influence the successful implementation of online learning.

\section{Student Learning Motivation}

Online learning characteristics provide easy access for both educators and students, and its flexibility can be accessed at flexible times and places. Online learning focuses on enhancing students' abilities and realizing independent learning (Wahyuningsih \& Makmur, 2017). However, the research conducted by Mulyanti et al. (2020) at public and private vocational schools in West Java stated that students felt that online learning was no more interesting than ordinary learning. Online learning has not provided better experience and productivity in mastering competencies but can provide motivation and convenience in learning (Syauqi et al., 2020). Interviews with productive subject teachers and students in both schools show that there are several obstacles and impacts on student learning motivation in online learning. Obstacles and impacts are presented in Table 3.

Table 3. Obstacles and Impacts of Student Motivation

\begin{tabular}{|c|c|c|}
\hline No. & Obstacles & Impact \\
\hline 1 & $\begin{array}{l}\text { Students feel bored and bored with } \\
\text { online learning }\end{array}$ & $\begin{array}{l}\text { Students feel that online learning is only given } \\
\text { assignments without being asked whether the material } \\
\text { has been understood or not, so students feel bored with } \\
\text { learning with the continuous assignment system. }\end{array}$ \\
\hline 2 & $\begin{array}{l}\text { Teachers have difficulty controlling } \\
\text { student activity online. }\end{array}$ & $\begin{array}{l}\text { The teacher only assesses the activeness of the initial } \\
\text { presence and the collection of assignments because to } \\
\text { assess activeness when learning is carried out is more } \\
\text { difficult because learning is not carried out using video } \\
\text { conferences. } \\
\text { With online learning, the teacher also cannot see } \\
\text { students' real conditions, whether to focus on learning } \\
\text { or not. }\end{array}$ \\
\hline 3 & $\begin{array}{l}\text { The available internet quota determines } \\
\text { student learning motivation. }\end{array}$ & $\begin{array}{l}\text { When the internet quota that students have is only a } \\
\text { little, students are also limited to downloading teaching } \\
\text { materials provided by the teacher, resulting in their } \\
\text { laziness in learning. }\end{array}$ \\
\hline
\end{tabular}


Based on this information, it is known that there are some obstacles in motivating students because students feel bored with online learning. Teachers also find it difficult to control student activeness in learning because, in essence, the mastery of online learning lies with the students themselves. Online learning requires the right design or scenario to keep students motivated to be active, interactive, and collaborative, especially in the main productive subjects in hotel accommodation. The hospitality system skills taught to students are essential in the hospitality sector, so students must be accustomed to practicing in their learning and presented with interesting material to foster their learning motivation (Syahputra et al., 2016).

Student learning motivation also needs to be nurtured with student learning assistance at home with parents. When students carry out face-to-face learning, the teacher is the person who will guide and provide material to these students. With online learning, the parental assistance contribution to learning at home is also essential to maintain student learning motivation. Some difficulties students and families face are those who do not master technology well, and parental assistance cannot be done full time because they have to work (Putra et al., 2020).

\section{Soft Skill Aspect}

Traditionally, soft skills are considered complementary to hard skills, namely the ability to carry out a certain activity/expertise (Cimatti, 2016). Soft skills are special abilities that can improve a person's job performance and career prospects (Abdullah-Al-Mamun, 2012). Soft skills can be interpreted as special competencies someone possesses in certain areas of expertise such as communication skills, working with a team, skills in a certain skill, etc. Research findings (Patacsil \& Tablatin, 2017) reveal that teamwork and soft skill communication are very important for graduates. Students' soft skills are very important in vocational school to prepare them to enter the work world (Mariah, 2012). At the Vocational School in hospitality accommodation, soft skills that must be developed and focus on attention are students' skills in the front office, housekeeping, food $\&$ beverage, and laundry.

Students' soft skills in these four productive subjects need to be appropriately developed because the hospitality sector is a field that provides services to the public or hotel users. As the first person to welcome customers, the front office requires communication skills to be interested and feel served in a particular hotel. As a servant who deals directly with consumers to clean rooms, housekeeping provides room-related services and requires communication skills classified as soft skills and needs to be properly trained. With the food \& beverage subject, they can make food and serve food to customers attractively. In essence, productive subjects in vocational schools in the hospitality accommodation sector also need to emphasize students' soft skills as a provision for them to enter the world of work because their work fields are directly related to customers. Including when productive learning is presented through online learning.

The application of online learning to teach these four subjects has problems. Based on the results of the interviews, the teacher felt that online learning had not provided better experience and productivity in mastering student competency skills in productive hospitality subjects. They should have mastered the essential hotel competencies in-depth but have not studied them optimally in this online learning. Teachers also find it difficult to provide learning that emphasizes soft student skills because, in this hotel accommodation field, productive learning must be done more through practice. In the research (Abdullah-Al-Mamun, 2012), soft skills seemed difficult to teach and even more difficult to assess in class. However, classrooms are ideal learning places where one can practice the basic knowledge of hospitality and facilitate interactive learning and knowledge transfer.

In general, the interviews with several participants have provided much information about online learning at the vocational school in Hotel accommodation. In implementing online learning policies, both students and teachers experience difficulties and constraints in certain conditions. It cannot be denied that this research is essential to be used as a basis for analyzing the strengths and weaknesses in online learning in the hotel accommodation department so that both schools and the government can correct deficiencies in the implementation of online learning if one day another pandemic occurs and requires learning to be carried out online or blended.

The closure of schools that have been implemented since March 2020 is an effort to break the chain of spreading Covid-19. However, as we all know, school closings are still ongoing today. 
This results in the vocational education level having difficulty in providing learning in productive subjects. As previously discussed, the hotel accommodation department has four productive subjects: front office, food \& beverage, housekeeping, and laundry. These four subjects need to be taught through practice. Never imagined before, students who should be able to practice Hotel skills at school and be supported by school facilities must switch to practicing from home with makeshift facilities. As a result, one of the teachers explained that with the implementation of this online learning, the necessary skills that hotel students must possess had not been maximally mastered. For this reason, in September 2020, specifically for vocational school, they are allowed to carry out practical learning at school in turn by complying with health protocols. The practical implementation schedule must be well prepared so that all students can carry out practical learning safely and optimize the time given to fully understand learning.

We conclude that online learning that is carried out at all levels of education, including the vocational level, has a positive and negative impact. The positive impact that is felt is the increasingly rapid development of technology globally. When a pandemic hits the world, technology becomes a solution, for that every human being is required to keep up with the speedy technological developments, including teachers, students, and parents. Teachers are required to master digital learning technology to present material to students. Students must follow the teacher's directions in implementing online learning, and parents must also be technology literate to assist their children while learning from home. The negative impact of students' motivation to learn through distance has decreased. A week requires more intensive teacher attention.

\section{CONCLUSION}

The implementation of online learning policies in vocational schools in hotel accommodation faces several obstacles on two aspects, namely hard and soft skills. Hard skill aspects that need to be considered include facilities, teacher digital competence, and student learning motivation. These three things need to be minimized by the obstacles that occur so that online learning is provided with quality and hard skills that students can master. Online learning at vocational schools hotel accommodation like schools also requires adequate facilities and infrastructure, starting from cell phones/gadgets, laptops, and internet data quotas. Teacher's digital competence is a challenge to continue to be improved so that the learning provided is of higher quality. Student learning motivation's stability needs to be maintained and continues to be grown to participate actively in learning. Even though online learning policies are challenging to apply in vocational schools in hospitality expertise, the quality must still be applied and maintained, especially in productive learning. Soft skills of vocational students in 4 productive subjects have not been taught optimally, and teachers feel that online learning does not optimally provide the basic competencies that students must possess.

\section{REFERENCES}

Abdullah-Al-Mamun, M. (2012). The soft skills education for the vocational graduate: Value as work readiness skills. British Journal of Education, Society \& Behavioural Science, 2(4), 326338. https://doi.org/10.9734/bjesbs/2012/1858

Adedoyin, O. B., \& Soykan, E. (2020). Covid-19 pandemic and online learning: the challenges and opportunities. Interactive Learning Environments, $0(0), \quad 1-13$. https://doi.org/10.1080/10494820.2020.1813180

Ally, M. (2019). Competency profile of the digital and online teacher in future education. International Review of Research in Open and Distance Learning, 20(2), 302-318. https://doi.org/10.19173/irrodl.v20i2.4206

Atsumbe, B. N., Raymond, E., Enoch, E. B., \& Duhu, P. (2012). Availability and utilization of elearning infrastructures in Federal University of Technology, Minna. Journal of Education and Practice, 3(13), 56-64. https://www.iiste.org/Journals/index.php/JEP/article/view/3056 
Aydin, S., Akkan, Y., Arpaz, E., \& Koparan, B. (2015). Online learning in vocational school: Focus on students' perceptions. Procedia - Social and Behavioral Sciences, 174, 3663-3667. https://doi.org/10.1016/j.sbspro.2015.01.1087

Cimatti, B. (2016). Definition, development, assessment of soft skills and their role for the quality of organizations and enterprises. International Journal for Quality Research, 10(1), 97-130. https://doi.org/10.18421/IJQR10.01-05

Creswell, J. W. (2013). Research design qualitative, quantitative, and mixed method approaches (p. 273). SAGE Publications.

Demuyakor, J. (2020). Coronavirus (Covid-19) and online learning in higher institutions of education: A survey of the perceptions of Ghanaian International Students in China. Online Journal of Communication and Media Technologies, 10(3). https://doi.org/10.29333/ojcmt/8286

Kaden, U. (2020). Covid-19 school closure-related changes to the professional life of a K-12 teacher. Education Sciences, 10(6), 1-13. https://doi.org/10.3390/educsci10060165

König, J., Jäger-biela, D. J., \& Glutsch, N. (2020). Adapting to online teaching during Covid-19 school closure: Teacher education and teacher competence effects among early career teachers in Germany. European Journal of Teacher Education, 43(4), 608-622. https://doi.org/10.1080/02619768.2020.1809650

Lucas, M., Bem-haja, P., Siddiq, F., Moreira, A., \& Redecker, C. (2021). The relation between inservice teachers' digital competence and personal and contextual factors: What matters most? Computers \& Education, $160, \quad 104052$. https://doi.org/10.1016/j.compedu.2020.104052

Mariah, S. (2012). Developing soft skills for the work readiness in industry of vocational high school students. International Conference on Vocational Education and Training (ICVET), 203211. https://eprints.uny.ac.id/24437/1/C-2.pdf

Ministry of Education and Culture of the Republic of Indonesia. (2020). Kemendikbud resmikan kebijakan bantuan kuota data internet 2020. Kemdikbud.Go.Id. https://www.kemdikbud.go.id/main/blog/2020/09/kemendikbud-resmikan-kebijakanbantuan-kuota-data-internet-2020

Moser, A., \& Korstjens, I. (2017). Series: Practical guidance to qualitative research. Part 1: Introduction. European Journal of General Practice, 23(1), 271-273. https://doi.org/10.1080/13814788.2017.1375093

Moser, A., \& Korstjens, I. (2018). Series: Practical guidance to qualitative research. Part 3: Sampling, data collection and analysis. European Journal of General Practice, 24(1), 9-18. https://doi.org/10.1080/13814788.2017.1375091

Mulyanti, B., Purnama, W., \& Pawinanto, R. E. (2020). Distance learning in vocational high schools during the covid-19 pandemic in West Java province, Indonesia. Indonesian Journal of Science and Technology, 5(2), 271-282. https://doi.org/10.17509/ijost.v5i2.24640

Naidu, S. (2006). E-learning: A guidebook of principles, procedures and practices. Commonwealth Educational Media Center for Asia.

Özer, M. (2020). Educational policy actions by the Ministry of National Education in the times of COVID-19 pandemic in Turkey. Kastamonu Education Journal, 28(3), 1124-1129. https://doi.org/10.24106/kefdergi.722280

Palmer, C., \& Bolderston, A. (2006). A brief introduction to qualitative research. Canadian Journal of Medical Radiation Technology, 37(1), 16-19. https://doi.org/10.1016/s08205930(09)60112-2 
Patacsil, F. F., \& Tablatin, C. L. S. (2017). Exploring the importance of soft and hard skills as perceived by IT internship students and industry: A gap analysis. Journal of Technology and Science Education, 7(3), 347-368. https://doi.org/10.3926/jotse.271

Putra, P., Liriwati, F. Y., Tahrim, T., Syafrudin, S., \& Aslan, A. (2020). The students learning from home experiences during Covid-19 school closures policy in Indonesia. Jurnal Iqra' : Kajian Ilmu Pendidikan, 5(2), 30-42. https://doi.org/10.25217/ji.v5i2.1019

Sadikin, A., Hamidah, A., Pinang, K., Jl, M., Ma, J., Km, B., Indah, M., Jaluko, K., Kode, K. M., \& Indonesia, P. (2020). Pembelajaran daring di tengah wabah Covid-19 (Online learning in the middle of the Covid-19 pandemic). BIODIK: Jurnal Ilmiah Pendidikan Biologi, 6(1), 214224. https://online-journal.unja.ac.id/biodik/article/view/9759

Syahputra, M. H. I., Mardji, Sudjimat, D. A., \& Agoessalim, S. R. (2016). Hotel system learning for SMK students of hospitality accommodation study program. AIP Conference Proceedings, 1778(October). https://doi.org/10.1063/1.4965790

Syauqi, K., Munadi, S., \& Triyono, M. B. (2020). Students' perceptions in vocational education on online learning during the covid-19 pandemic. International Journal of Evaluation and Research in Education (IJERE), 9(4), 881-886. https://doi.org/10.11591/ijere.v9i4.20766

Triyono, M. B. (2015). The Indicators of Instructional Design for E- learning in Indonesian Vocational High Schools. Procedia - Social and Behavioral Sciences, 204(November 2014), 54-61. https://doi.org/10.1016/j.sbspro.2015.08.109

Triyono, M. B., \& Utami, P. (2017). Pembelajaran e-learning pendidikan vokasi. UNY Press.

Wagiran, W. (2008). The importance of developing soft skills in preparing vocational high school graduates. Universitas Negeri Yogyakarta.

Wahyuningsih, D., \& Makmur, R. (2017). E-Learning teori dan aplikasi. Penerbit Informatika.

Zhang, W., Wang, Y., Yang, L., \& Wang, C. (2020). Suspending classes without stopping learning: China's education emergency management policy in the COVID-19 outbreak. Journal of Risk and Financial Management, 13(3), 55. https://doi.org/10.3390/jrfm13030055 